\title{
Sensitivity of tropical seabirds to El Niño precursors
}

\author{
Carol A. Devney, ${ }^{1,4}$ Michael Short, ${ }^{2}$ and Bradley C. Congdon ${ }^{3}$ \\ ${ }^{1}$ Australian Institute of Marine Science, School of Marine and Tropical Biology, \\ James Cook University, P.O. Box 6811, Cairns, Queensland 4870, Australia \\ ${ }^{2}$ Marine Technical Support Unit, Queensland Parks and Wildlife Service, P.O. Box 2006, Cairns, Queensland 4870 Australia \\ ${ }^{3}$ School of Marine and Tropical Biology, James Cook University, P.O. Box 6811, Cairns, Queensland 4870 Australia
}

\begin{abstract}
Intense El Niño events severely impact seabird populations, often months in advance of peak temperature anomalies. The trophic mechanisms responsible for these impacts are unknown but are assumed to operate at seasonal scales and to be linked to ocean productivity changes. Precursors to El Niño events include changes in both sea-surface temperature and the depth of the $20^{\circ} \mathrm{C}$ thermocline. Foraging piscivorous seabirds are known to be sensitive to both thermocline depth and sea-surface temperature change, but the potential influence of these phenomena on breeding dynamics is unknown. Using 18 years of data on three seabirds of the western tropical Pacific, we show that pelagic seabird breeding participation is directly and independently related to changes in both surface chlorophyll concentration and thermocline depth that occur well in advance of El Niño generated seasurface temperature anomalies. In contrast, breeding in an inshore foraging species is not correlated with any environmental/biological parameters investigated. These findings demonstrate that El Niño related phenomena do not affect seabird prey dynamics solely via productivity shifts at seasonal scales, nor in similar ways across different seabird foraging guilds. Our results also suggest that population declines observed in the western tropical Pacific may be directly related to the frequency and intensity of El Niño anomalies over the study period.
\end{abstract}

Key words: $20^{\circ} \mathrm{C}$ thermocline; Anous stolidus; breeding participation; El Niño Southern Oscillation; Great Barrier Reef, Australia; precursor impacts; productivity; Sterna bergii; Sterna fuscata; western tropical Pacific.

\section{INTRODUCTION}

The El Niño Southern Oscillation (ENSO) is a major driver of both global climate and associated variation in sea-surface temperature (SST; Fiedler 2002). Intense El Niño events have been linked to severe negative impacts on both temperate and tropical seabird populations (Schreiber and Schreiber 1984, Bertram et al. 2005). In general, these impacts are attributed to seasonal-scale crashes in productivity at lower tropic levels linked to deepening of the nutricline (remotely forced by Kelvin waves [Barber and Chavez 1983]) and an associated lack of nutrient upwelling. Such seasonal-scale decreases in nutrient availability are clearly evident in large-scale temperate upwelling systems (Cane 1983, Norton and McLain 1994) and in cold tropical regions (Cronin and Kessler 2002), but evidence of similar-scale processes in warm tropical systems is limited. Similarly, the magnitude and even direction of ecological responses to ENSO-related variation in tropical marine environments appears to differ by region (Roemmich and McGowan 1995, Lavaniegos et al. 1998, Dandonneau et al. 2004), or species (Edwards and Richardson 2004), with these

Manuscript received 3 April 2008; revised 21 July 2008; accepted 16 September 2008. Corresponding Editor: M. Wikelski.

${ }^{4}$ E-mail: carol.devney@jcu.edu.au differences being attributable to complex regional upwelling dynamics and/or other physical processes (Messié and Radenac 2006). In fact, variance in ecological responses to this type of phenomenon is not exclusive to the ENSO. Impacts of the North Atlantic Oscillation on seabird breeding demographics are also strongly geographically patterned (Sandvik et al. 2008). In addition, recent data further suggest that detrimental impacts may also involve fine-scale (day-to-day) trophic stresses not linked to seasonal-scale declines in productivity (Peck et al. 2004, Erwin and Congdon 2007). Clearly, a more regionally specific and comprehensive mechanistic understanding of how El Niño related phenomena impact biological processes in tropical marine systems is needed in order to clarify current inconsistencies in the available data. Such clarification is also essential if predicted climate change impacts in these systems are to be successfully managed into the future (Congdon et al. 2007).

Oceanographic data suggest that there are significant precursors to El Niño events that can vary in intensity and direction both spatially and temporally (GarcésVargas et al. 2005, Terray and Dominiak 2005, Ruiz et al. 2006). The most well documented of these precursors is changes in the depth of the $20^{\circ} \mathrm{C}$ Pacific Ocean thermocline (McPhaden and $\mathrm{Yu}$ 1999, Harrison and Vecchi 2001). Changes in thermocline characteristics are 
known to affect biological productivity and hence prey availability directly (Sarmiento et al. 2004), but they are also known to significantly influence the distribution and abundance of marine fish (Brill et al. 1999, Kitagawa et al. 2004, Schaefer et al. 2007) and zooplankton (Fernández-Álamo and Färber-Lorda 2006) via processes that do not necessarily involve productivity changes. For example, during foraging, fish-eating seabirds in the eastern tropical Pacific are sensitive to changes in both the depth and the gradient of the thermocline via their association with pelagic underwater predators (Spear et al. 2001, Ballance et al. 2006). However, the influence of thermocline depth on reproductive success in these same taxa has not been examined. Similarly, in the western tropical Pacific, where the thermocline is considerably deeper (Fiedler and Talley 2006), nothing is known of its influence on seabird reproductive biology and the mechanisms by which these effects are manifest.

We investigated 18 years of data on the population dynamics of three tropical seabirds breeding in the western Pacific to determine how breeding participation related to ENSO intensity, associated SST changes and/or precursive depth changes in the $20^{\circ} \mathrm{C}$ Pacific Ocean thermocline. We were specifically interested in whether the effects of thermocline depth changes could be consistently identified and if so, whether they could be related to either productivity decreases and/or to changes in the accessibility of prey independent of background changes in productivity.

\section{Methods}

\section{Location and data collection}

Michaelmas Cay $\left(16^{\circ} 36^{\prime} \mathrm{S}, 145^{\circ} 59^{\prime} \mathrm{E}\right)$, in the farnorthern Great Barrier Reef, Australia, is an important tropical seabird nesting site that supports populations of some of the most abundant species in tropical regions (Sibley and Monroe 1990). Approximately monthly counts of all breeding seabirds present on Michaelmas Cay were made between 1984 and 2001. The breeding population present each month was estimated using the number of nest sites observed (King et al. 1992). Based on these data we calculated an index of breeding participation for each year of the study period for three species, the Sooty Tern (Sterna fuscata), Common Noddy (Anous stolidus), and Crested Tern (S. bergii). The pelagic foraging Sooty Tern and Common Noddy are the most common species breeding at Michaelmas Cay. These two species are also among the most abundant seabird taxa in tropical regions (Sibley and Monroe 1990). The inshore foraging Crested Tern is the third most abundant seabird breeding on the cay and is also the most common tern species in Australia (Serventy et al. 1971). Crested Terns breed all along the Australian coastline in tropical, subtropical, and temperate habitats, as well as throughout the tropical Indo and western Pacific Oceans (Blakers et al. 1984). The importance of Michaelmas Cay as a breeding site for these three common and widespread species identifies this location as a good model system for examining the potential influence of these same processes elsewhere.

\section{Environmental descriptors}

To explore how breeding participation for each species was influenced by ENSO associated environmental variation and/or potential ENSO precursors, the mean number of breeding pairs in each year was regressed against the multivariate ENSO Index (MEI) (Wolter and Timlin 1993, 1998), SST, and the depth of the $20^{\circ} \mathrm{C}$ thermocline at a range of different spatial and temporal scales.

Bimonthly MEI values (in 0.001 of standard deviations) were downloaded from the National Oceanic and Atmospheric Administration (available online). ${ }^{5}$ Monthly satellite SST data were available for the entire study period from the Reynolds/National Centers for Environmental Prediction Satellite for an area between $14^{\circ}$ and $18^{\circ} \mathrm{S}$ latitude and $144^{\circ}$ and $148^{\circ} \mathrm{E}$ longitude (data available online). ${ }^{6}$ Data for the depth of the $20^{\circ} \mathrm{C}$ isotherm, which represents the thermocline, or depth where the temperature gradient is a maximum (Pickard and Emergy 1990), were provided by the Australian Bureau of Meteorology Research Centre. Data were extracted monthly for the region between $0^{\circ}$ to $30^{\circ} \mathrm{S}$ latitude and $140^{\circ} \mathrm{E}$ to $140^{\circ} \mathrm{W}$ longitude. The data have a $1^{\circ} \times 2^{\circ}$ latitude-longitude grid resolution and is created using an optimal interpolation technique that combines hydrographic measurements with moored temperature measurements from the tropical ocean and atmosphere observation program (Smith 1995). Average annual thermocline depths were calculated for two subregions in the western tropical Pacific: the West Pacific warm pool $\left(0^{\circ}-3^{\circ} \mathrm{S}, 140^{\circ}-159^{\circ} \mathrm{E}\right)$ and the Coral Sea region near Michaelmas Cay $\left(13^{\circ}-16^{\circ} \mathrm{S}, 146^{\circ}-149^{\circ} \mathrm{E}\right)$.

\section{Productivity}

Both coastal upwelling, driven by localized tidal and wind forcing, and oceanic upwelling, occur in the Coral Sea region near Michaelmas Cay (Andrews and Gentien 1982). The ENSO appears to drive interannual variation in both these upwelling dynamics (Wolanski and Pickard 1985). Large-scale variations in primary productivity, due to changes in upwelling intensity, are observable as changes in the chlorophyll $a$ content of the surface waters (Lorenzen 1970). Therefore, to document changes in upwelling dynamics and examine how these changes may be linked to other oceanographic and climatic phenomena, in situ chlorophyll $a$ data were obtained from a long-term chlorophyll monitoring program (beginning in 1993 and ongoing as of this writing). This program has sampling stations located in

\footnotetext{
5 /http://www.cdc.noaa.gov/people/klaus.wolter/MEI/ table.html $>$

${ }^{6}\langle$ http://poet.jpl.nasa.gov $\rangle$
} 
TABLE 1. Results of regressions testing the influence of oceanic factors on the mean number of breeding pairs of the three main breeding seabird species of Michaelmas Cay, Great Barrier Reef, Australia.

\begin{tabular}{|c|c|c|c|c|c|c|c|c|c|}
\hline \multirow[b]{2}{*}{ Year } & \multicolumn{3}{|c|}{ Sooty Tern } & \multicolumn{3}{|c|}{ Common Noddy } & \multicolumn{3}{|c|}{ Crested Tern } \\
\hline & $F_{1,16}$ & $r$ & $P$ & $F_{1,16}$ & $r$ & $P$ & $F_{1,16}$ & $r$ & $P$ \\
\hline \multicolumn{10}{|c|}{ Annual average MEI } \\
\hline$n$ & 1.830 & 0.320 & 0.195 & 3.390 & 0.418 & 0.084 & 2.034 & 0.336 & 0.173 \\
\hline$n-1$ & 0.006 & 0.019 & 0.941 & 0.229 & 0.119 & 0.639 & 0.486 & 0.172 & 0.496 \\
\hline$n+1$ & 10.647 & 0.632 & 0.005 & 4.930 & 0.485 & 0.041 & 0.026 & 0.040 & 0.875 \\
\hline \multicolumn{10}{|c|}{ Annual average SST } \\
\hline$n$ & 0.010 & 0.025 & 0.923 & 0.369 & 0.150 & 0.552 & 3.733 & 0.435 & 0.071 \\
\hline$n-1$ & 2.033 & 0.345 & 0.174 & 0.779 & 0.222 & 0.391 & 0.948 & 0.244 & 0.346 \\
\hline$n+1$ & 1.358 & 0.288 & 0.262 & 1.840 & 0.331 & 0.195 & 0.452 & 0.171 & 0.511 \\
\hline
\end{tabular}

Notes: The annual average multivariate El Niño index (MEI) and sea-surface temperature (SST) were compiled at three distinct temporal (real-time, precursor, and lagged) scales and were compared with the number of breeding pairs of Sooty Terns (Sterna fuscata), Common Noddies (Anous stolidus), and Crested Terns (S. bergii). Associations are presented between the number of breeding pairs of each species in each year $(n)$ and MEI/SST each year, in the year prior $(n-1)$ and in the following year $(n+1)$. Significant relationships $(P \leq 0.05)$ are shown in boldface.

the Far Northern $\left(13^{\circ} \mathrm{S}\right)$ and Cairns $\left(16^{\circ} \mathrm{S}\right)$ transects of the Great Barrier Reef. Data for the period 1993-2001 were provided by the Australian Institute of Marine Science and were used to calculate average annual indices of surface chlorophyll concentration for each year during the sample period (data available online). ${ }^{7}$

\section{RESULTS}

\section{Precursor impacts of the ENSO}

Sooty Tern and Common Noddy breeding participation in each year $(n)$ was significantly negatively correlated with the MEI for the following year $(n+1$; Table 1, Fig. 1), but not for the same year $(n)$ or for the year prior $(n-1)$. A relationship between Crested Tern breeding participation and MEI was not present at any temporal scale (Table 1). This implies significant negative associations between as yet unidentified ENSO precursors and average breeding population sizes of both pelagic species, but not the inshore foraging species.

\section{Thermocline and SST changes}

During the buildup to an El Niño event, warm surface waters along the equatorial region are redistributed so that in general the $20^{\circ} \mathrm{C}$ thermocline deepens in the eastern tropical Pacific while it shoals in the west (Meinen and McPhaden 2000). However, our results indicate that in the western Pacific $\left(140-160^{\circ}\right.$ E) the direction and timing of ENSO-related thermocline change varied with latitude. Our analyses show that during high positive periods of the MEI (El Niño-like conditions) significant shoaling of the thermocline occurred at the equator $\left(0-3^{\circ} \mathrm{S} ; r=0.815, F_{1,16}=\right.$ 31.699, $P<0.001)$ as expected for the western Pacific (Meinen and McPhaden 2000), but that in the Coral Sea region adjacent to Michaelmas Cay $\left(13^{\circ}-16^{\circ} \mathrm{S}\right)$ more intense El Niño-like conditions produced small-scale

\footnotetext{
${ }^{7}$ http://adc.aims.gov.au:9555/chloro/do/gotoStart.do $\rangle$
}

deepening of the thermocline $\left(r=0.605, F_{1,16}=9.249, P\right.$ $=0.008$; Fig. 2). These thermocline depth changes in the region around Michaelmas Cay did not occur exactly 12 months ahead of the contrasting changes in thermocline depth at the equator, but nevertheless occurred well in advance (10 months; $r=0.546, F_{1,19}=8.086, P=0.010$; Fig. 3), making them clear ENSO precursors.

Localized changes in thermocline depth for the Coral Sea region correlate directly with changes in Sooty Tern and Common Noddy breeding participation at Michaelmas Cay. Our analyses confirmed that breeding

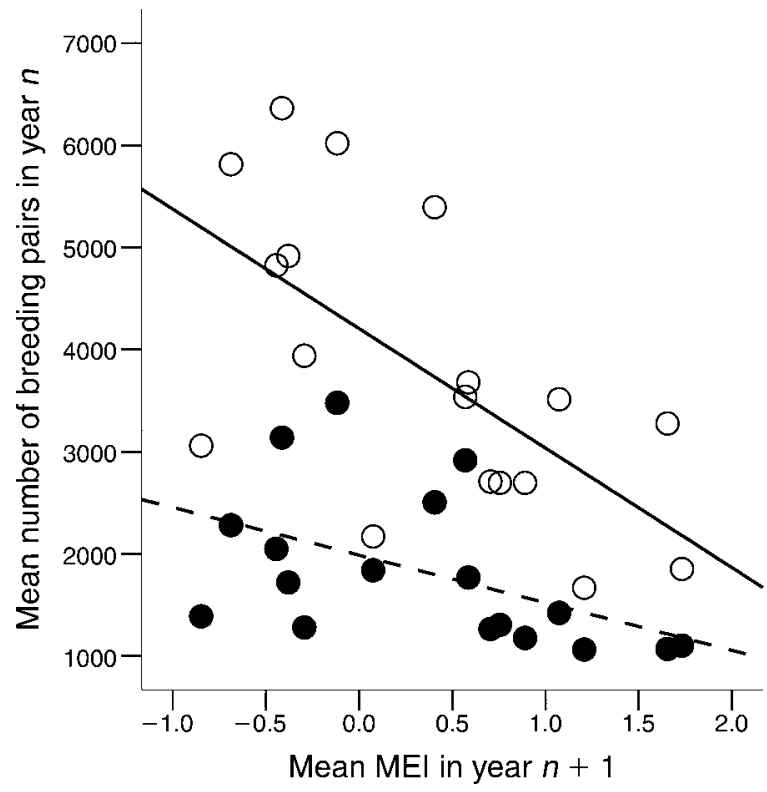

FIG. 1. Number of breeding pairs of pelagic terns and annual averages of multivariate El Niño index (MEI). The average annual number of breeding pairs counted from 1984 to 2001 on Michaelmas Cay (Great Barrier Reef, Australia) for the Sooty Tern (open circles; $r=0.632, P=0.005$ ) and Common Noddy (solid circles; $r=0.485, P=0.041$ ) in each year $(n)$ is shown in relation to mean annual MEI in the following year $(n$ +1 ). The figure is modified from Congdon et al. (2007). 


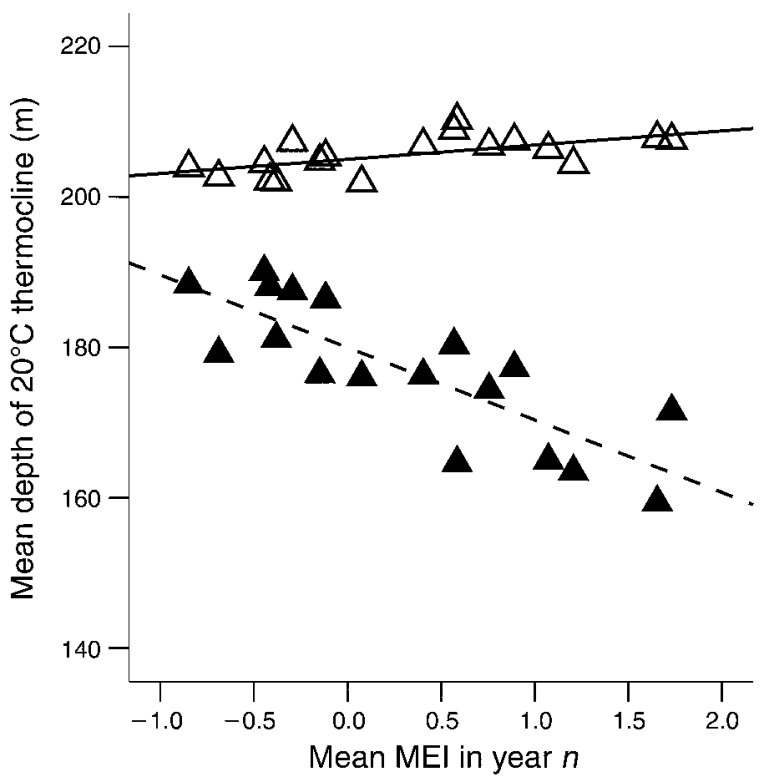

FIG. 2. Depth of the $20^{\circ} \mathrm{C}$ thermocline relative to MEI at different latitudes. Differences in thermocline and MEI correlations are shown between equatorial $\left(0-3^{\circ} \mathrm{S}\right.$ and 140 $160^{\circ} \mathrm{E}$, solid triangles; $\left.r=0.815, P<0.001\right)$ and higher-latitude tropical regions $\left(13-16^{\circ} \mathrm{S}\right.$ and $146-149^{\circ} \mathrm{E}$, open triangles; $r=$ $0.605, P=0.008)$ of the western Pacific Ocean.

populations of both species decreased as the average thermocline depth in the vicinity of Michaelmas Cay $\left(13-16^{\circ} \mathrm{S}\right)$ deepened (Sooty Tern, $r=0.484, F_{1,16}=$ 4.902, $P=0.042$; Common Noddy, $r=0.537, F_{1,16}=$ $6.470, P=0.022$; Fig. 4A). In contrast, there was no significant relationship between thermocline depth and the number of breeding pairs of Crested Terns $(r=$ $\left.0.005, F_{1,16}=0.000, P=0.983\right)$ at Michaelmas Cay.

During the development phase of El Niño, anomalous SSTs are first seen in the central equatorial Pacific, then propagate eastward to reach the South American coast several months later (Wang 1995). However, changes in annual breeding participation of all three species at Michaelmas Cay in the western tropical Pacific were not related to localized changes in surface water temperature at any temporal scale (Table 1).

\section{Productivity changes}

The surface chlorophyll concentration in the region $13-16^{\circ} \mathrm{S}$ was significantly positively related to Sooty Tern and Common Noddy breeding participation at Michaelmas Cay during 1993-2001 $\left(r=0.773, F_{1,7}=\right.$ $10.400, P=0.015 ; r=0.667, F_{1,7}=5.612, P=0.050$, for Sooty Terns and Common Noddies, respectively; Fig. 4B) over this same period. Crested Tern presence at the cay was not related to annual changes in surface chlorophyll concentration in the region $\left(r=0.342, F_{1,7}\right.$ $=0.925, P=0.368)$.

Combined, $20^{\circ} \mathrm{C}$ thermocline depth and surface chlorophyll concentrations in the Coral Sea explained $>95 \%$ of the observation variation in breeding partic- ipation of Sooty Terns at Michaelmas Cay each year (Table 2, Fig. 5A, B). Similar but less robust relationships were also found for Common Noddy breeding participation (Table 2). Importantly, there was no direct relationship between chlorophyll concentration and thermocline depth $\left(r=0.057, F_{1,7}=0.023, P=0.884\right)$ implying that each of these factors influences breeding participation independently.

\section{DisCusSION}

We observed significant negative associations between two potential ENSO precursors (thermocline depth change, chlorophyll concentration) and average breeding participation of both pelagic tern species at Michaelmas Cay. Such findings imply that in the western Coral Sea region at least, pelagic species are sensitive to both these ENSO precursors up to a year in advance of ENSO indices registering a formal event.

Although unusual, observations of El Niño precursor impacts are not completely novel. Similar relationships have been documented for a southern temperate breeding shearwater species (Puffinus griseus) in the southwest Pacific Ocean (Lyver et al. 1999) and for multiple species breeding along the southern African coast (La Cock 1986). Trophic mechanisms responsible for both these earlier described relationships are unknown. Untested general hypotheses previously proposed for each of these observations both implicate SST anomalies as the process responsible. Respectively, these hypotheses are (1) that SST increases in the northwest Pacific significantly alter prey abundance/availability during shearwater migration which in turn influences breeding participation and (2) that a decline in upwelling along the African coast associated with lessening of the trade winds and a pooling of warm surface waters

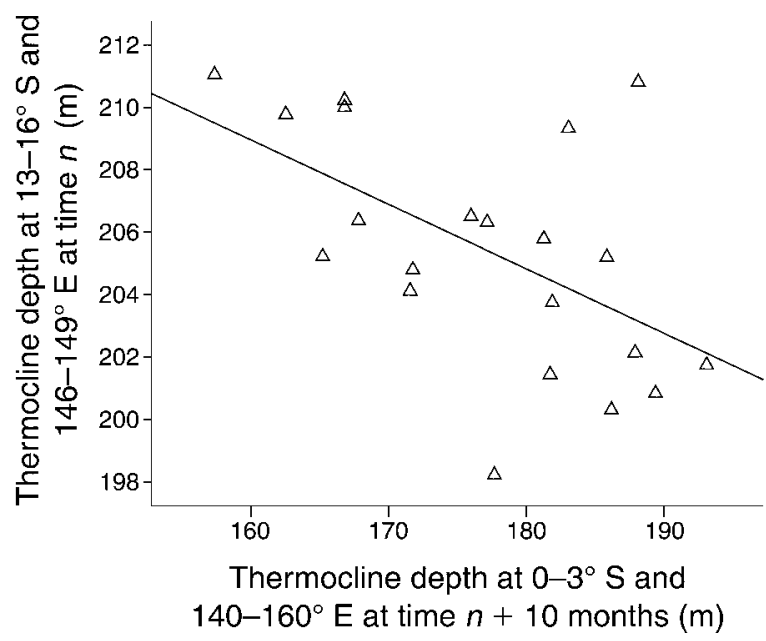

FIG. 3. Precursive changes in 10-month average depths of the $20^{\circ} \mathrm{C}$ thermocline $(\mathrm{m})$ that occur at higher-latitude tropical regions $\left(13-16^{\circ} \mathrm{S}\right.$ and $\left.146-149^{\circ} \mathrm{E}\right)$ in advance of those at equatorial regions $\left(0-3^{\circ} \mathrm{S}\right.$ and $\left.140-160^{\circ} \mathrm{E}\right) 10$ months later $(r=$ $0.546, P=0.010)$. 
reduces resource availability to seabirds in this region both during an El Niño year and in the year previous.

In contrast, our analyses demonstrate that this same phenomenon in the tropical south-western Pacific is not associated with precursive changes in SST. Instead it is linked to changes in productivity and/or thermocline depth that occur independent of SST variation. Both these phenomena appear to have significant and relatively immediate impacts on the food available to birds during the pre-breeding season. We have no evidence that variation in these two phenomena is related. Instead, our analyses suggest that both phenomena independently influence Sooty Tern and Common Noddy breeding participation.

That productivity changes significantly influence breeding participation is consistent with previous findings for temperate systems (Stenseth and Mysterud 2002, Durant et al. 2003, Inchausti et al. 2003) where intense El Niño events disrupt upwelling (McGowan et al. 1998, Wilson et al. 2003), or induce changes in the timing of peak productivity of seabird prey species (Hedd et al. 2002, Frederiksen et al. 2004). In general, and primarily excluding the cold tropical regions of the Humboldt Current, upwelling in tropical systems occurs at a much smaller and more localized scale than in temperate systems (Kessler 2006). However, despite these substantial differences in upwelling dynamics, our data suggest that pelagic seabird breeding participation in tropical systems, ocean productivity and ENSO related changes in oceanographic and atmospheric conditions are similarly linked.

The deepening of the thermocline we observed off eastern Australia was relatively minor compared to deepening that occurs in the eastern Pacific (Fiedler and Talley 2006), or to the level of shoaling that occurs in the western Pacific at lower latitudes (Fig. 2). Despite this, thermocline depth significantly influenced breeding participation independent of productivity changes. This finding highlights a previously unidentified trophic impact of El Niño in tropical marine systems and suggests that changes in thermocline depth may directly influence prey species distribution, abundance or accessibility to seabirds over relatively short (within-season) time periods.

The mechanisms by which thermocline depth changes may influence prey accessibility are currently unknown. However, two non-mutually exclusive possibilities can be identified. First, in most tropical marine habitats, pelagic foraging seabirds feed by gleaning prey items from or just below the surface of the water, while flying (Higgins and Davies 1996), resulting in a strong reliance on subsurface predators such as tuna and/or marine mammals to drive prey to the surface (Au and Pitman 1986, Ballance et al. 1997, Jaquemet et al. 2004). In the early stages of an El Niño event, thermocline shoaling in the western tropical Pacific (McPhaden and Yu 1999) causes tuna foraging resources in this region to decline as the area of highest productivity moves into the central
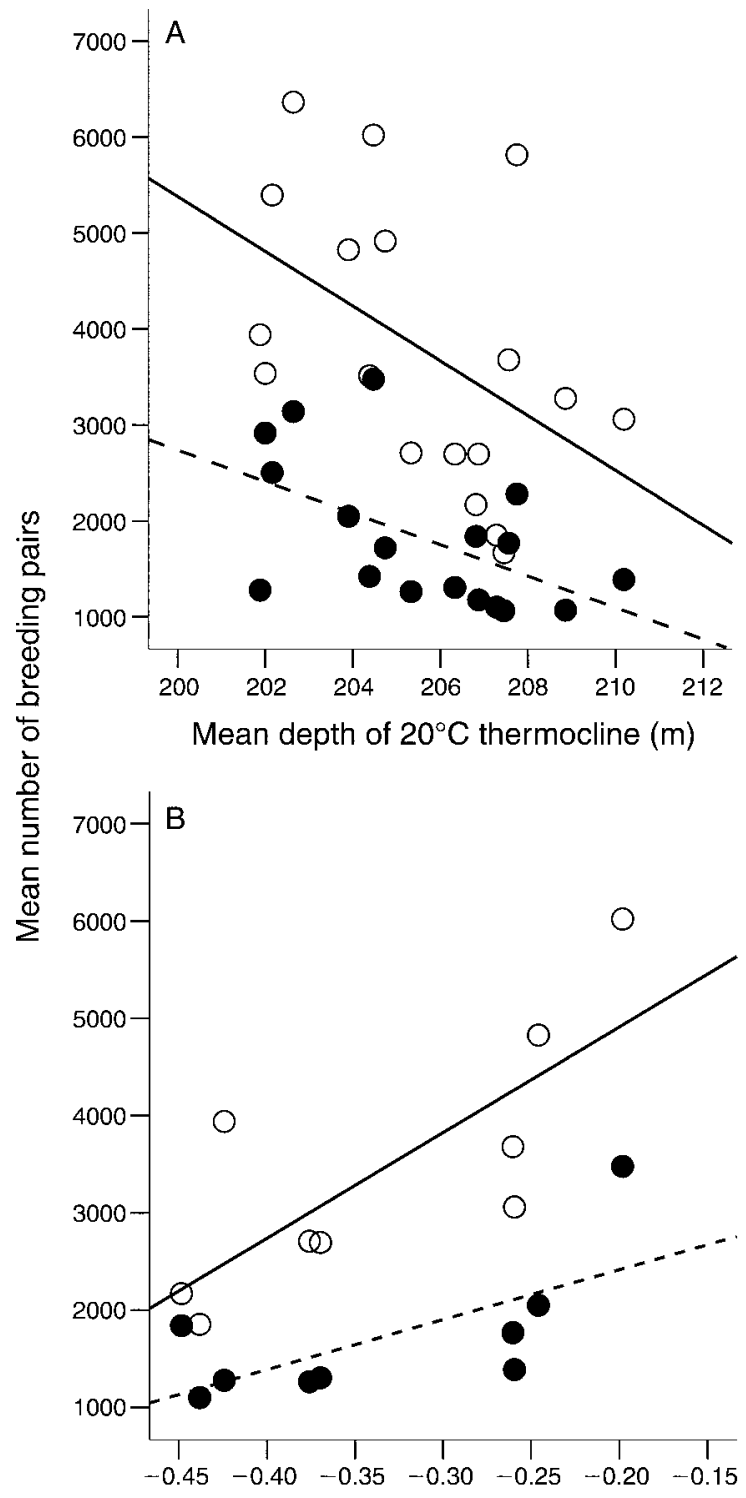

Mean $\log _{10}$ (surface chlorophyll concentration)

FIG. 4. Number of breeding pairs of pelagic terns at Michaelmas Cay relative to (A) mean annual depth of the $20^{\circ} \mathrm{C}$ thermocline and (B) in situ measurements of mean annual $\log _{10}$ (surface chlorophyll $a$ concentration) (measured in $\mathrm{mg} / \mathrm{m}^{3}$ ) for Sooty Terns (open circles; $r=0.484, P=0.042$ ) and Common Noddies (solid circles; $r=0.537, P=0.022$ ).

Pacific (Lehodey 2001). The resulting redistribution of subsurface predators presumably impacts upon prey accessibility to foraging seabirds in the region. This is because pre-breeding or breeding seabirds are central placed foragers whose movements are restricted by the need to remain in the vicinity of breeding sites (Orians and Pearson 1979).

Second, variation in thermocline dynamics in the western tropical Pacific may directly influence the concentration of forage fish, independent of changes in the distribution or abundance of marine subsurface 
TABLE 2. Step-wise multiple regression analysis of breeding participation in Sooty Terns and Common Noddies vs. the two environmental predictor variables.

\begin{tabular}{lcccccr}
\hline \hline & \multicolumn{5}{c}{$r_{\mathrm{p}}$} & \\
\cline { 2 - 5 } \multicolumn{1}{c}{ Step } & Cumulative $r$ & Increase in $r$ & Chlorophyll & Thermocline & Model $F_{2,6}$ & $P$ \\
\hline Sooty Tern & & & & & & \\
$\quad 1$ & $\mathbf{0 . 7 7 3}$ & & 0.773 & & $\mathbf{1 0 . 4 0 0}$ & $\mathbf{0 . 0 1 5}$ \\
2 & $\mathbf{0 . 9 7 2}$ & 0.199 & 0.962 & -0.928 & $\mathbf{5 0 . 7 6 7}$ & $<\mathbf{0 . 0 0 1}$ \\
Common Noddy & & & & & & \\
$\quad 1$ & 0.737 & & 0.701 & -0.316 & 3.571 & 0.095 \\
2 & $\mathbf{0 . 6 6 7}$ & -0.070 & 0.667 & & $\mathbf{5 . 6 1 2}$ & $\mathbf{0 . 0 5 0}$ \\
\hline
\end{tabular}

Notes: Variables are chlorophyll ( $\log _{10}\left[\right.$ surface chlorophyll $a$ concentration], measured in $\mathrm{mg} / \mathrm{m}^{3}$ ) and thermocline (thermocline depth at $13-16^{\circ} \mathrm{S}$ and $146-149^{\circ} \mathrm{E}$ ). The statistic $r_{\mathrm{p}}$ is the partial correlation of each variable with the number of breeding pairs. Significant relationships $(P \leq 0.05)$ are shown in boldface.

predators. This idea is untested (Fiedler et al. 1998) but is supported by data from the eastern tropical and equatorial Pacific (reviewed by Ballance et al. 2006), where changes in thermocline structure can induce vertically migrating prey to aggregate and become more readily available to subsurface predators (Spear et al. 2001). However it must also be remembered that in the western Pacific the thermocline is on average much deeper (150-200 $\mathrm{m}$ in the west vs. $15-50 \mathrm{~m}$ in the east)

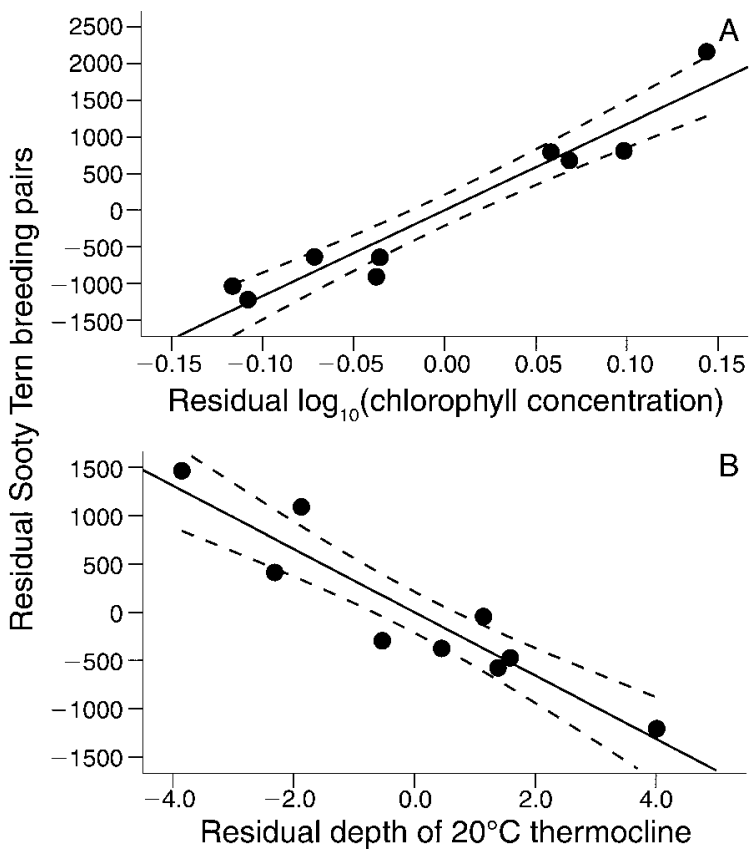

FIG. 5. Partial regression plots of factors affecting the mean annual number of breeding pairs of Sooty Terns at Michaelmas Cay. Values are the residuals from a regression of breeding pairs plotted against residual (A) $\log _{10}$ (surface chlorophyll $a$ concentration) (measured in $\mathrm{mg} / \mathrm{m}^{3} ; F_{1,7}=81.673, r=0.9597, P$ $<0.001$ ) and (B) depth of the $20^{\circ} \mathrm{C}$ thermocline (effects of thermocline depth and chlorophyll concentration, respectively, controlled; $\left.F_{1,7}=41.688, r=-0.9250, P<0.001\right)$. Dashed lines are $95 \%$ confidence limits. The best-fit regression model includes both chlorophyll concentration and thermocline $\left(F_{2,6}\right.$ $=50.767, r=0.972, P<0.001)$. and so structural changes at depth would not necessarily be expected to have as great an impact on prey accessibility in this region.

Breeding participation of Crested Terns did not respond to precursory changes in either the depth of the $20^{\circ} \mathrm{C}$ thermocline, or to variation in ocean productivity. These results are consistent with previous comparative findings among inshore and pelagic foraging species (Surman et al. 2002). Both Sooty Terns and Common Noddies have been shown to fare poorly throughout most of their range during periods of intense El Niño conditions (Schreiber and Schreiber 1984, Duffy 1990, Megysei and Griffin 1996, Ramos et al. 2006), while sympatric populations of Crested Terns have remained unaffected (Schreiber and Schreiber 1984).

Inshore foragers such as Crested Terns feed singularly or in pairs over reefs, lagoons and beaches, near breeding islands (Surman and Wooller 2003, Le Corre and Jaquemet 2005) and plunge dive for prey so do not rely in the same way on the presence of subsurface predators (Higgins and Davies 1996). Inshore species also have the highest diversity of prey among seabird taxa, a characteristic that may buffer them against decreases in the availability of any single prey type (Diamond 1983). In contrast, pelagic foraging species generally feed on similar prey while in large multispecies flocks (Jaquemet et al. 2004) often at vast distances from breeding colonies (Ballance and Pitman 1999, Schreiber et al. 2002, Surman and Wooller 2003).

Our findings add to increasing evidence that El Niño conditions not only interfere with major seasonal-scale trophic processes, but that in at least some tropical marine systems, they also add multiple additional finescale within-season trophic stresses (Peck et al. 2004, Erwin and Congdon 2007) that vary by species. The trophic relationships represented by these findings have a number of significant potential implications for pelagic foraging terns in the western tropical Pacific. First, they suggest that the resources required by these species for non-breeding season survival, or during the buildup to breeding, are influenced by the same precursory oceanographic events that have previously only been 


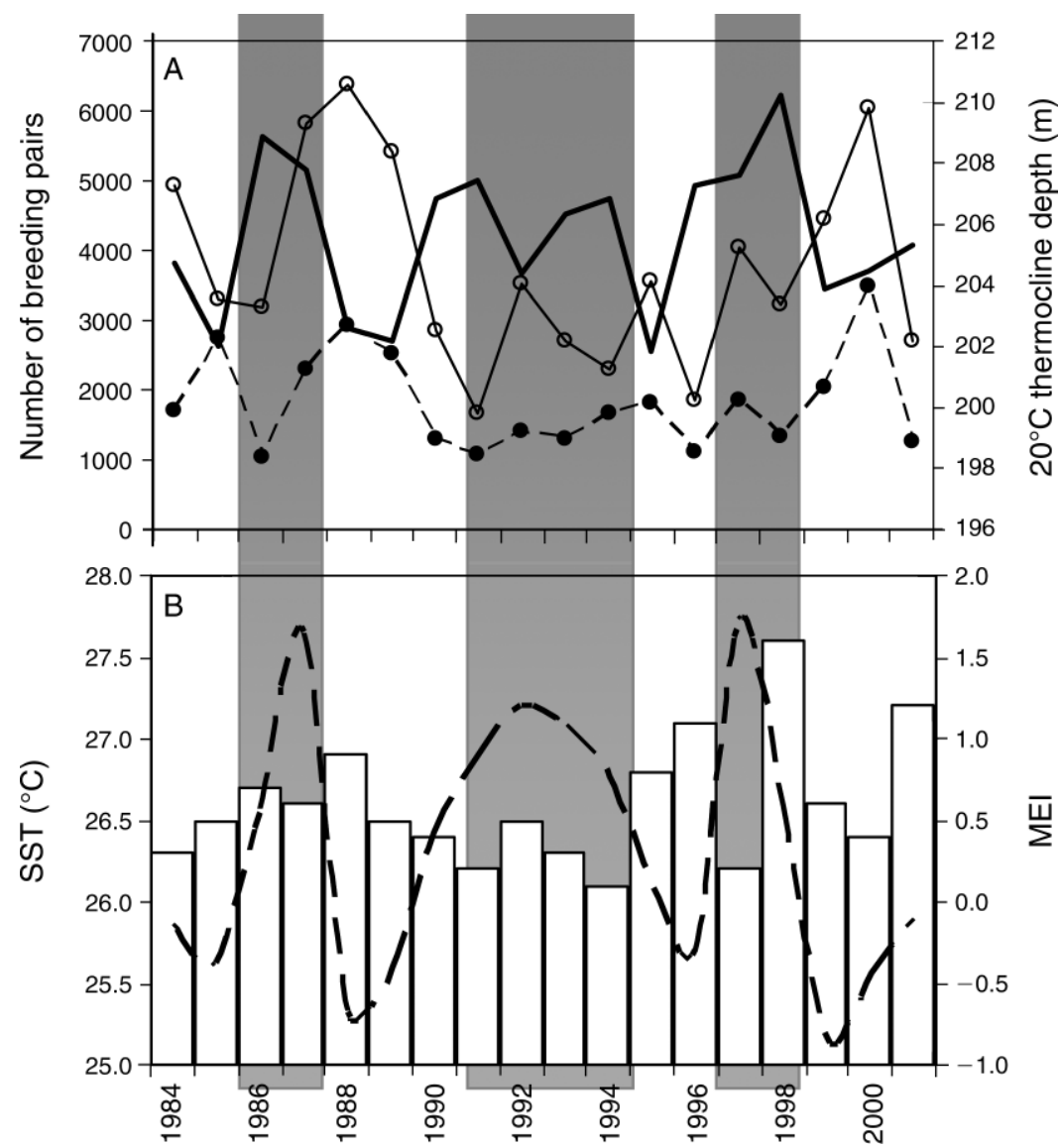

FIG. 6. (A) Time series of mean annual number of breeding pairs of Sooty Terns and Common Noddies (solid and dashed thin lines, respectively, left vertical axis) and the $20^{\circ} \mathrm{C}$ thermocline depth averaged annually within $13-16^{\circ} \mathrm{S}$ and $146-149^{\circ} \mathrm{E}$ (heavy line, right vertical axis). (B) Time series of sea surface temperature (SST) averaged within $14-18^{\circ} \mathrm{S}$ and $144-148^{\circ} \mathrm{E}$ (histogram bars, left vertical axis) and MEI (dashed line, right vertical axis). The data are relative to the 1984-2001 time period, with El Niño events identified by gray-shaded bars.

observed to impact temperate taxa. Unfortunately, at the moment very little is known about the non-breeding distribution and resource use of tropical breeding terns that can be used to further test this idea. Second, they suggest that the significant population fluctuations observed for both pelagic species breeding at Michaelmas Cay over 18 years (Queensland Parks and Wildlife Service, unpublished data) may be directly linked to contemporary increases in the frequency and intensity of ENSO events (Timmerman et al. 1999, Zhang et al. 2008). This possibility is significant and requires further investigation, as it suggests that similar impacts may be occurring in declining pelagic seabird populations throughout both the Great Barrier Reef (Heatwole et al. 1996, Baker et al. 2004, Batianoff and Cornelius 2005) and greater western Pacific region (Lyver et al. 1999, Benoit and Bretagnolle 2002).

\section{ACKNOWLEDGMENTS}

Data were collected by numerous Queensland Parks and Wildlife Service personnel, most importantly, John Cornelius and Michael Short. Steven Stanley (James Cook University) helped extract the thermocline data that were provided by Claire Spillman (Australian Bureau of Meteorology). The Great Barrier Reef Marine Park Authority and the Australian Institute of Marine Science provided the chlorophyll data used in this assessment. Craig Steinberg and Janice Lough (Australian Institute of Marine Science) provided technical advice. Funding was provided by the Queensland Parks and Wildlife Service, an AIMS@JCU Ph.D. Scholarship, and the Australian Research Council LP 0562157.

\section{Literature Cited}

Andrews, J. C., and P. Gentien. 1982. Upwelling as a source of nutrients for the Great Barrier Reef ecosystems: a solution to Darwin's question? Marine Ecology Progress Series 8:257269.

Au, D. W. K., and R. L. Pitman. 1986. Seabird interactions with dolphins and tuna in the eastern tropical Pacific. Condor 88:304-317.

Baker, G. B., M. Double, N. Beck, M. Holdsworth, S. Bryant, T. Aleks, J. Shaw, and M. Hallam. 2004. Report on 2004 field season and update of Herald Cays longitudinal dataset for the period of 1992-2004. Coral Sea National Nature Reserve, Marine Protected Areas Management Section, Department of the Environment and Heritage, Canberra, Australia. 
Ballance, L. T., and R. L. Pitman. 1999. Foraging ecology of tropical seabirds. Pages 2057-2071 in N. J. Adams and R. H. Slotow, editors. Proceedings of the 22nd International Ornithology Congress, Durban. BirdLife South Africa, Johannesburg, South Africa.

Ballance, L. T., R. L. Pitman, and P. C. Fiedler. 2006. Oceanographic influences on seabirds and cetaceans of the eastern tropical Pacific: a review. Progress in Oceanography 69:360-390.

Ballance, L. T., R. L. Pitman, and S. B. Reilly. 1997. Seabird community structure along a productivity gradient: Importance of competition and energetic constraint. Ecology 78: $1502-1518$.

Barber, R. T., and F. P. Chavez. 1983. Biological consequences of El Niño. Science 222:1203-1210.

Batianoff, G. N., and N. J. Cornelius. 2005. Birds of Raine Island: population trends, breeding behaviour and nesting habitats. Proceedings of the Royal Society of Queensland 112:1-29.

Benoit, M. P., and V. Bretagnolle. 2002. Seabirds of the southern lagoon of New Caledonia; distribution, abundance and threats. Waterbirds 25:202-213.

Bertram, D. F., A. Harfenist, and B. D. Smith. 2005. Ocean climate and El Niño impacts on survival of Cassin's Auklets from upwelling and downwelling domains of British Columbia. Canadian Journal of Fisheries and Aquatic Sciences 62: 2841-2853.

Blakers, M., S. J. J. F. Davies, and P. N. Reilly. 1984. The atlas of Australian birds. RAOU and Melbourne University Press. Melbourne, Victoria, Australia.

Brill, R. W., B. A. Block, C. H. Boggs, K. A. Bigelow, E. V. Freund, and D. J. Marcinek. 1999. Horizontal movements and depth distribution of large adult yellowfin tuna (Thunnus albacares) near the Hawaiian Islands, recorded using ultrasonic telemetry: implications for the physiological ecology of pelagic fishes. Marine Biology (Berlin) 133:395408.

Cane, M. A. 1983. Oceanographic events during El Niño. Science 222:1189-1202.

Congdon, B. C., C. A. Erwin, D. R. Peck, G. B. Baker, M. C. Double, and P. O'Neill. 2007. Vulnerability of seabirds on the Great Barrier Reef to climate change. Pages 427-463 in P. Marshall and J. Johnson, editors. Great Barrier Reef ecological vulnerability assessment. Great Barrier Reef Marine Park Authority, Townsville, Australia.

Cronin, M. F., and W. S. Kessler. 2002. Near surface conditions at $0^{\circ}, 110^{\circ} \mathrm{W}$ during the onset of the $1997-98 \mathrm{El}$ Niño. Deep-Sea Research I 49:1-17.

Dandonneau, Y., P.-Y. Deschamps, J.-M. Nicolas, H. Loisel, J. Blanchot, Y. Montel, F. Thieuleux, and G. Bécu. 2004. Seasonal and interannual variability of ocean color and composition of phytoplankton communities in the North Atlantic, equatorial Pacific and South Pacific. Deep-Sea Research II 51:303-318.

Diamond, A. W. 1983. Feeding overlap in some tropical and temperate seabird communities. Studies in Avian Biology No. 8:24-46.

Duffy, D. C. 1990. Seabirds and the 1982-84 El Niño southern oscillation. Pages 395-415 in P. W. Glynn, editor. Global ecological consequences of the 1982-83 El Niño southern oscillation. Elsevier, Amsterdam, The Netherlands.

Durant, J. M., T. Anker-Nilssen, and N. C. Stenseth. 2003. Trophic interactions under climate fluctuations: the Atlantic puffin as an example. Proceedings of the Royal Society B 270: 1461-1466.

Edwards, M., and A. J. Richardson. 2004. Impact of climate change on marine pelagic phenology and trophic mismatch. Nature 430:881-884.

Erwin, C. A., and B. C. Congdon. 2007. Day-to-day variation in sea-surface temperature negatively impacts sooty tern
(Sterna fuscata) foraging success on the Great Barrier Reef, Australia. Marine Ecology Progress Series 331:255-266.

Fernández-Álamo, M. A., and J. Färber-Lorda. 2006. Zooplankton and the oceanography of the eastern tropical Pacific: a review. Progress in Oceanography 69:318-359.

Fiedler, P. C. 2002. Environmental change in the eastern tropical Pacific Ocean: review of ENSO and decadal variability. Marine Ecology Progress Series 244:265-283.

Fiedler, P. C., J. Barlow, and T. Gerrodette. 1998. Dolphin prey abundance determined from acoustic backscatter data in eastern Pacific surveys. Fisheries Bulletin 96:237-247.

Fiedler, P. C., and L. D. Talley. 2006. Hydrography of the eastern tropical Pacific: a review. Progress in Oceanography 69:143-180.

Frederiksen, M., M. P. Harris, F. Daunt, P. Rothery, and S. Wanless. 2004. Scale-dependent climate signals drive breeding phenology of three seabird species. Global Change Biology 10:1214-1221.

Garcés-Vargas, J., W. Schneider, R. Abarca del Río, R. Martínez, and E. Zambrano. 2005. Inter-annual variability in the thermal structure of an oceanic time series station off Ecuador (1990-2003) associated with El Niño events. DeepSea Research Part I Oceanographic Research Papers 52: 1789-1805.

Harrison, D. E., and A. Vecchi. 2001. El Niño and La Niña: equatorial Pacific thermocline depth and sea surface temperature anomalies, 1986-1998. Geophysical Research Letters 28:1051-1054.

Heatwole, H., P. O'Neill, M. Jones, and M. Preker. 1996. Longterm population trends of seabirds on the Swain Reefs, Great Barrier Reef. CRC Reef Research Centre, Townsville, Australia.

Hedd, A., J. L. Ryder, L. L. Cowen, and D. F. Bertram. 2002. Inter-annual variation in the diet, provisioning and growth of Cassin's Auklet at Triangle Island, British Columbia: responses to variation in ocean climate. Marine Ecology Progress Series 229:221-232.

Higgins, P. J., and S. J. J. F. Davies. 1996. Handbook of Australian, New Zealand and Antarctic Birds. Volume 3. Snipe to Pigeons. Oxford University Press, Melbourne, Australia.

Inchausti, P., C. Guinet, M. Koudil, J. P. Durbec, C. Barbraud, H. Weimerskirch, Y. Cherel, and P. Jouventin. 2003. Interannual variability in the breeding performance of seabirds in relation to oceanographic anomalies that affect the Crozet and the Kerguelen sectors of the Southern Ocean. Journal of Avian Biology 34:170-176.

Jaquemet, S., M. Le Corre, and H. Weimerskirch. 2004. Seabird community structure in a coastal tropical environment: importance of associations with sub-surface predators and of fish aggregating devices (FADs). Marine Ecology Progress Series 268:281-292.

Kessler, W. S. 2006. The circulation of the eastern tropical Pacific: a review. Progress in Oceanography 69:181-217.

King, B. R., J. T. Hicks, and J. Cornelius. 1992. Population changes, breeding cycles and breeding success over six years in a seabird colony at Michaelmas Cay, Queensland. Emu 92: $1-10$.

Kitagawa, T., S. Kimura, H. Nakata, and H. Yamada. 2004. Diving behavior of immature, feeding Pacific bluefin tuna (Thunnus thynnus orientalis) in relation to season and area: the East China Sea and the Kuroshio-Oyashio transition region. Fisheries Oceanography 13:161-180.

La Cock, G. D. 1986. The southern oscillation, environmental anomalies, and mortality of two southern African seabirds. Climate Change 8:173-184.

Lavaniegos, E. B., J. R. Gómez-Gutierrez, J. R. Lara-Lara, and S. Hernández-Vázquez. 1998. Long-term changes in zooplankton volumes in the California Current system. The Baja California region. Marine Ecology Progress Series 169:55-64. 
Le Corre, M., and S. Jaquemet. 2005. Assessment of the seabird community of the Mozambique Channel and its potential use as an indicator of tuna abundance. Estuarine Coastal and Shelf Science 63:421-428.

Lehodey, P. 2001. The pelagic ecosystem of the tropical Pacific Ocean: dynamic spatial modelling and biological consequences of ENSO. Progress in Oceanography 49:439-468.

Lorenzen, C. J. 1970. Surface chlorophyll as an index of the depth, chlorophyll content and primary productivity of the euphotic layer. Limnology and Oceanography 15:479-480.

Lyver, P. O. B., H. Moller, and C. Thompson. 1999. Changes in Sooty Shearwater Puffinus griseus chick production and harvest precede ENSO events. Marine Ecology Progress Series 188:237-248.

McGowan, J. A., D. R. Cayan, and L. M. Dorman. 1998. Climate-ocean variability and ecosystem response in the Northeast Pacific. Science 281:210-217.

McPhaden, M. J., and X. Yu. 1999. Genesis and evolution of the 1997-1998 El Niño. Science 283:950-954.

Megysei, J. L., and C. R. Griffin. 1996. Breeding biology of the Brown Noddy on Tern Island, Hawaii. Wilson Bulletin 108: 95-114.

Meinen, C. S., and M. J. McPhaden. 2000. Observations of warm water volume changes in the equatorial Pacific and their relationship to El Niño and La Niña. Journal of Climate 13:3551-3559.

Messié, M., and M.-H. Radenac. 2006. Seasonal variability of the surface chlorophyll in the western tropical Pacific from SeaWiFS data. Deep-Sea Research I 53:1581-1600.

Norton, J., and D. McLain. 1994. Diagnostic patterns of seasonal and interannual temperature variation off the west coast of the United States: local and remote large scale atmospheric forcing. Journal of Geophysical Research 99: 16019-16030.

Orians, G. H., and N. E. Pearson. 1979. On the theory of central place foraging. Pages $155-177$ in D. J. Horn, R. Mitchell, and G. R. Stair, editors. Analysis of ecological systems. Ohio State University Press, Columbus, Ohio, USA.

Peck, D. R., B. V. Smithers, A. K. Krockenberger, and B. C. Congdon. 2004. Sea surface temperature constrains wedgetailed shearwater foraging success within breeding seasons. Marine Ecology Progress Series 281:259-266.

Pickard, G. L., and W. J. Emergy, editors. 1990. Descriptive physical oceanography: an introduction. Pergamon Press, Sydney, Australia.

Ramos, J. A., A. M. Maul, J. Bowler, L. Wood, R. Threadgold, S. Johnson, D. Birch, and S. Walker. 2006. Annual variation in laying date and breeding success of Brown Noddies on Aride Island, Seychelles. Emu 106:81-86.

Roemmich, D., and J. McGowan. 1995. Climatic warming and the decline of zooplankton in the California Current. Science 267:1324-1326.

Ruiz, J. E., I. Cordery, and A. Sharma. 2006. Impact of midPacific Ocean thermocline on the prediction of Australian rainfall. Journal of Hydrology 317:104-122.

Sandvik, H., T. Coulson, and B.-E. Sæther. 2008. A latitudinal gradient in climate effects on seabird demography: results from interspecific analyses. Global Change Biology 14:703713.

Sarmiento, J. L., N. Gruber, M. A. Brzezinski, and J. P. Dunne. 2004. High latitude controls of thermocline nutrients and low latitude biological productivity. Nature 427:56-60.

Schaefer, K. M., D. W. Fuller, and B. A. Block. 2007. Movements, behavior, and habitat utilization of yellowfin tuna (Thunnus albacares) in the northeastern Pacific Ocean, ascertained through archival tag data. Marine Biology (Berlin) 152:503-525.

Schreiber, E. A., C. J. Feare, B. A. Harrington, B. G. J. Murray, W. B. J. Robertson, and G. E. Woolfenden. 2002. Sooty tern (Sterna fuscata). In A. Poole and F. Gill, editors. Birds of North America. The Birds of North America, Inc., Philadelphia, Pennsylvania, USA.

Schreiber, R. W., and E. A. Schreiber. 1984. Central Pacific seabirds and the El Niño southern oscillation: 1982 to 1983 perspectives. Science 225:713-715.

Serventy, D., V. Serventy, and J. Warham. 1971. The handbook of Australian sea-birds. A. H. and A. W. Reed, Ltd., Sydney, Australia.

Sibley, C. G., and B. L. J. Monroe. 1990. Distribution and taxonomy of the birds of the world. Yale University Press, New Haven, Connecticut, USA.

Smith, N. R. 1995. An improved system for tropical ocean subsurface temperature analyses. Journal of Atmospheric and Oceanic Technology 12:850-870.

Spear, L. B., L. T. Ballance, and D. G. Ainley. 2001. Response of seabirds to thermal boundaries in the tropical Pacific: the thermocline versus the Equatorial Front. Marine Ecology Progress Series 219:275-289.

Stenseth, N. C., and A. Mysterud. 2002. Climate, changing phenology, and other life history traits: nonlinearity and match-mismatch to the environment. Proceedings of the National Academy of Science (USA) 99:13379-13381.

Surman, C., M. Moran, A. Burbidge, R. Wooller, and D. Gaughan. 2002. Identification and conservation of food fish for Abrolhos seabirds. National Heritage Trust, Perth, Australia.

Surman, C. A., and R. D. Wooller. 2003. Comparative foraging ecology of five sympatric terns at a sub-tropical island in the eastern Indian Ocean. Journal of Zoology (London) 259:219 230.

Terray, P., and S. Dominiak. 2005. Indian Ocean sea surface temperature and El Niño-Southern Oscillation: a new perspective. Journal of Climate 18:1351-1366.

Timmerman, A., J. Oberhuber, A. Bacher, M. Esch, M. Latif, and E. Roeckner. 1999. Increased El Niño frequency in a climate model forced by future greenhouse warming. Nature (London) 398:694-697.

Wang, B. 1995. Interdecadal changes in El Niño onset in the last four decades. Journal of Climate 8:267-285.

Wilson, S. G., J. H. Carleton, and M. G. Meekan. 2003. Spatial and temporal patterns in the distribution and abundance of macro-zooplankton on the southern North West Shelf, Western Australia. Estuarine Coastal and Shelf Science 56: 897-908.

Wolanski, E., and G. L. Pickard. 1985. Long-term observations of currents on the central Great Barrier Reef continental shelf. Coral Reefs 4:47-57.

Wolter, K., and M. S. Timlin. 1993. Monitoring ENSO in COADS with a seasonally adjusted principal component index. Pages 52-57 in Proceedings of the 17th Climate Diagnostics Workshop. NOAA/N MC/CAC, NSSL, Oklahoma Climate Survey, CIMMS and the School of Meteorology, University of Oklahoma, Norman, Oklahoma.

Wolter, K., and M. S. Timlin. 1998. Measuring the strength of ENSO: how does 1997/98 rank? Weather 53:315-324.

Zhang, Q., Y. Guan, and H. Yang. 2008. ENSO amplitude change in observation and coupled models. Advances in Atmospheric Sciences 25:361-366. 